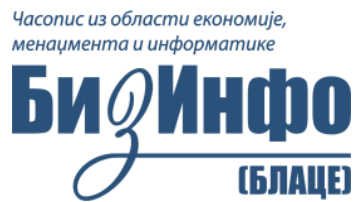

Година 2019, волумен 10, број 1, стр. 69-83

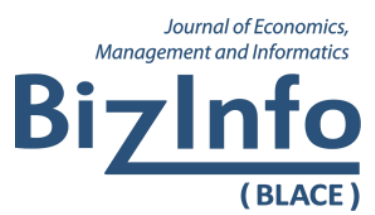

Year 2019, Volume 10, Number 1, pp. 69-83

Стручни рад/ Professional paper

УДК/UDC: 656.1.053.7(497.11)

504.6:534.322.3(497.11)

doi:10.5937/bizinfo1901069P

\title{
ROAD TRAFFIC \\ AS A SOURCE OF NOISE POLLUTION \\ (CASE STUDY: TRSTENIK MUNICIPALITY)
}

\author{
DRUMSKI SAOBRAĆAJ \\ KAO IZVOR ZAGAĐENJA BUKOM \\ (STUDIJA SLUČAJA OPŠTINA TRSTENIK)
}

Ljiljana Pecić ${ }^{1}$, Predrag Pravdić ${ }^{2}$

Bachelor School for Technical Engineering, Trstenik

Abstract: Noise is a known pollutant of the environment, especially noise coming from road traffic. This paper describes the study of noise levels at 4 locations in the town of Trstenik, which was carried out during the 2017. Based on the obtained results, appropriate analyzes were carried out and recommendations for reducing the noise level to the allowed limits are given. Key words: noise, road traffic, pollution

Sažetak: Buka je poznati zagađivač životne sredine, posebno buka koja dolazi od drumskog saobraćaja. U ovom radu je opisano istraživanje nivoa buke na 4 lokacije u gradu Trstenik, koje je sprovedeno tokom leta 2017. godine. Na osnovu dobijenih rezultata, izvedene su odgovarauce analize $i$ date su preporuke za svođenje nivoa buke u dozvoljene granice.

Key words: buka, drumski saobraćaj, zagađenje

\section{INTRODUCTION}

Environmental noise pollution refers to sound levels in a human environment that are higher than acceptable levels caused by traffic, construction,

\footnotetext{
${ }^{1}$ ljpecic72@gmail.com

2 thepera81@gmail.com
} 
industrial, and individual recreational activities. It can have serious, direct or indirect, consequences on human health, such as hearing loss or sleep disorders, blood pressure and mental disorders. Noise can activate the premature development of some diseases, and in extreme cases can lead to death. The effects of noise exposure during the night can be significantly different from the effects of the day (Zatežić, 2009). Due to the development of the economy in Serbia (growth of 5.6\% in 2008, 7.1\% in 2007 and $5.6 \%$ in 2006), the intensity of traffic is significantly increased (Mihajlović and Stošić, 2016).

This leads to unacceptable noise levels, especially near the highways. Traffic noise is, therefore, the largest source of noise in the environment. More than $60 \%$ of the city's population in Serbia is exposed to levels of traffic noise that are considered to be seriously endangering the quality of life. Approximately $25 \%$ of the population is exposed to so many levels of noise that there have been health consequences, as confirmed by the Institute for Hygiene and Medical Ecology from Belgrade (Izveštaj o realizaciji G2G projekta za Srbiju G2G09/SB/5/5, 2011).

According to the European Committee for Environment and Health, there are difficulties in relation to inadequate legislation and noise limit values for noise, inadequate noise monitoring in urban areas, lack of noise zoning activities in the spatial planning process, inadequate position of industrial areas, lack of projects noise protection, insufficient noise control emitted by motor vehicles, and inadequate traffic management (Kostadinović and Grujić, 2003).

Wszołek (2017) sugested that cumulation of various noise categories (traffic noise, industrial noise etc.) requires additional regulations (corrections) that take into account various acceptable values and normative time periods both in da-time and night-time. Also, he concluded that the acceptable value for the night-time period after taking into account the cumulative effects with the existing traffic noise, should be reduced to $42.8 \mathrm{~dB}$.

Swedish doctors warn that traffic noise in metropolises can seriously endanger health and shorten the life expectancy of a modern man. The most endagered is the health of those who live near busy and noisy streets. Because of the constant exposure to sounds greater than 60 decibels (DB), leaking blood pressure, there is a nervous breakdown, even a stroke, as confirmed by the example of 24,238 subjects aged 18 to 80 years (Fernandes de Souza et al., 2015).

Numerous studies indicate that traffic is an allpresent source of noise. In general, the problem of traffic noise is solved in one of three ways: the noise 
control at its source, the directional sound, or the use of regulatory rules and controls. Sound direction is successfully implemented by building a barrier to protect against traffic noise.

\section{NOISE IN LIFE- ENVIRONMENT}

For more than 20 years, the EU's environmental noise policy is based on legislation that prescribes the maximum permissible level for road vehicles, planes, machines or applies international agreements, along with certification procedures that ensure equipment at the time of production meets the noise limit values of sanctioned directives.

The 1996 „Green Paper“document defines the primary goal of a future noise strategy to "no one should be exposed to noise levels that could endanger health and quality of life." The structure of the new noise strategy in the environment is defined by the Environmental Noise Directive 2002/43/EC, which refers to the assessment and management of noise in the environment (as well as additional EU Directives relating to the noise of the Motor Vehicle Exhaust Syistem 70/157/EEC, Noise Emissions from Motorcycles 97/24/EEC and Household Appliances 86/549/EEC).

In Serbia, the directives (which are in accordance with the above mentioned EU directives) are used.

\subsection{ROAD TRAFFIC NOISE}

In the 21st century, traffic is considered as one of the biggest causes of noise. WHO published in 2011 a study about the burdens of disease from environmental noise.In the study conclusion is noted that about 1 million years of healthy life are lost in the EU every year due to noise reasons. According to Morillas (2002), 90\% of the population of Cáceres (Spain) is affected by a sound level of $65 \mathrm{~dB}(\mathrm{~A})$ during working time.

The noise level changes depending on the type and number of transportation means, the structure of the transportation means, speed, road surface, roads and railways, and similar. Road traffic, from the aspect of its development, number and basic characteristics, creates an extremely higher noise level than rail traffic.

Jakovljevic et al. (2009) concluded that the most significant noise source in urban areas is road traffic noise, according to the interviewed residents.

For example, an alone passenger car at a speed of $35 \mathrm{~km} / \mathrm{h}$ causes a noise of about $50 \mathrm{~dB}$, and at a speed of $75 \mathrm{~km} / \mathrm{h}$ creates noise level of $59 \mathrm{~dB}$, while alone truck at a speed of $40 \mathrm{~km} / \mathrm{h}$ causes a noise level of $76 \mathrm{~dB}$ (Mihajlović 
and Stošić, 2016). When designing new roads, traffic lanes and parking lots, it is necessary to meet the criteria that daily noise levels do not exceed $65 \mathrm{~dB}$ (A) (Guidelines for road traffic noise abatement).

Detailed studies (Alessandroni et al., 2017) have shown that the noise level is affected by: the roughness of the substrate, the speed of vehicle movement, the condition of the road surface, the type of tire and its load, and the type of road surface.

Noise from motor vehicles mostly comes from two independent noise sources: from the engine and from the touch of the tire surface with the road surface. In urban driving conditions, where the number of stops and start-ups is greatest, noise is produced mostly by the engine. On highways, where it drives faster, the touch of the tire and highway at high speed produces the most noise, while the full exhaust system is the most loud exhaust system.

In urban areas, the noise generated during driving a motor vehicle with respect to the primary source, can be divided into three groups (Grubiša, 2013):

1. Noise from the passage of the vehicle through the air;

2. Noise of the vehicle;

3. The noise of the interaction between the tire and the running surface.

Noise of air-flow, as a source of noise emissions, is not considered as a more influential noise factor the vehicle emits in the environment (at low and medium speeds). The noise generated by the vehicle movements is the noise emission generated by vehicle components that act when starting the vehicle itself, and depends on the engine speed (structural engine noise, air intake, fan noise and exhaust system). The noise level is higher for freight vehicles than for passenger vehicles, and this effect is particularly evident at lower transmission rates.

The most important sources of vehicle's noise are (Grubiša, 2013):

- exhaust system,

- suction system,

- engine (noise of combustion and mechanical noise),

- cooling system,

- aerodynamic noise and

- pneumatic.

The noise from the interaction of the tire and the driving surface is the noise generated by rolling the wheels along the road surface. In particular, it comes at higher speeds, in which its intensity increases, while at the same time it reduces engine noise (noise then works with a higher gear). The smooth road 
surface lowers AS noise, but it is not safe. In recent years, in developed countries, great attention has been paid to the construction of low-noise roads with a porous cover that lowers the noise of the car by $3-4$.

Figure 1. The main causes of noise and vibration of the car

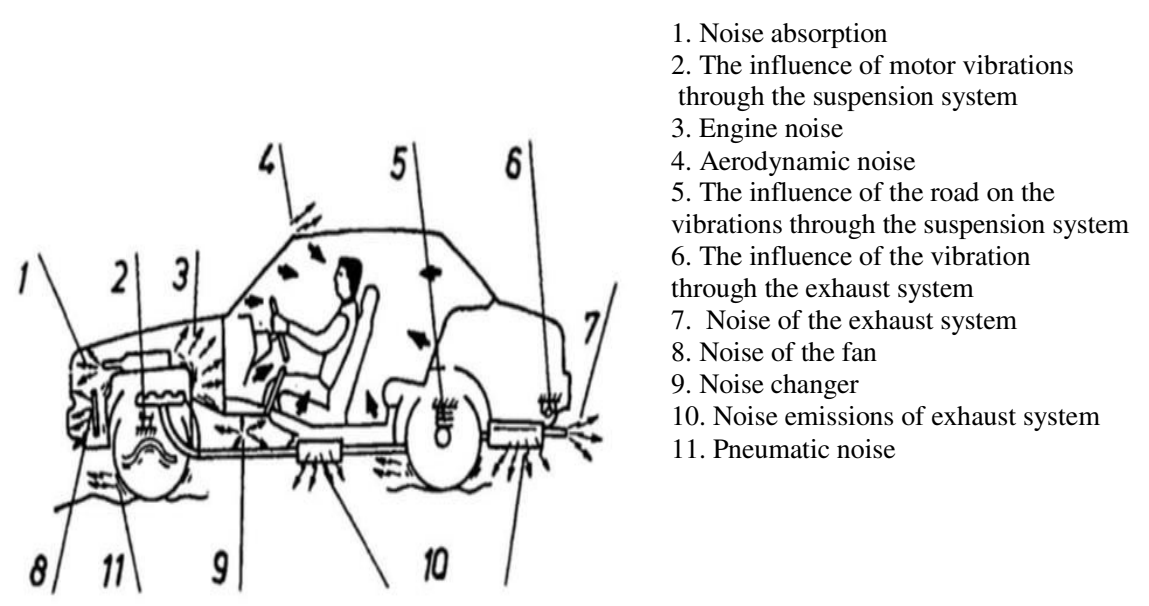

Source: Grubiša, 2013

\section{PROTECTION MEASURES FROM TRAFFIC NOISE}

In the case of the impact of car noise on humans, it is useful to distinguish three aspects:

- the influence of noise on the driver from the position of professional harm,

- the influence of noise on passenger car or bus passengers (acoustic comfort) and

- the impact of automobile traffic noise on the local population.

Botteldooren et al. (2011) analyze the influence of road traffic on noise annoyance in neighborhoods. Their research also specifically analyzes the association between road traffic noise and several diseases in suburban and urban areas. If the volume of the noise exceeds a certain limit, there is an overload of the human nervous system, resulting in increased functional activity of the nervous structures of the brain, attention and memory diminishes, the accuracy of the work and reaction rate decreases, the reception and experience of information becomes more difficult and the body's movement becomes dormant ".(Grubiša, 2013).

Khajenasiri et al. (2016) conducted study on 50 students at Shiraz University of Medical Sciences in which each person was considered as its own control to assess the effect of noise on her or his performance at the sound level of 
70,90 and $110 \mathrm{~dB}$ by using two factors of physical features and the creation of different conditions of sound source (applaying two-arm coordination test). They found that sound levels of 70 and $90 \mathrm{~dB}$ had no significant association with error rate and the length of performance but sound level of $110 \mathrm{~dB}$ was important contributor to decreased individuals performances.

Night noise causes health hazards already at individual levels below $45 \mathrm{~dB}$, if the difference between the individual level and the background noise is more than $3 \mathrm{~dB}$. Noise above $55 \mathrm{~dB}$ is considered as noise pollution. Noise in the range 65 to $75 \mathrm{~dB}$ causes stress to the body. This can lead to arterial hypertension (high blood pressure), cardiovascular disease and myocardial infarction (heart attack) ( Panulinová and Harabinová, 2013).

In order to reduce the noise of road traffic and transport, various types of barriers are installed, while motors, tires, exhaust systems, etc. are being improved on the vehicles themselves.

Mitigation of noise is possible by planting high green plants, as well as by setting protective insulating barriers (of course, where possible).

The barrier can achieve a reduction of $5 \mathrm{~dB}$ when it is high enough to bend the view of the highway. After preventing visibility, with each additional meter of its height, the barrier achieves about $1.5 \mathrm{~dB}$ of additional noise reduction. (Guidelines for road traffic noise abatement). Efficient barriers typically can reduce noise levels from 5 to $10 \mathrm{DBs}$. Under the law in force in the EU, there is a need to set up a barrier against traffic noise in areas where there are 4 "black" points at a distance of $100 \mathrm{~m}$, where the noise is four places higher than $60 \mathrm{~dB} .{ }^{1}$

Barriers in urban areas should be designed differently from barriers in more open suburban and rural areas and should be designed to avoid causing monotony to drivers. The primary goal of using the barrier should be to avoid the tunnel effect for drivers. This can be achieved by using different shapes, materials and finishing surfaces for the barriers (Portal građevinske industrije, 2011.)

Vegetation, placed around important roads, if it is high enough, wide and thick, can reduce traffic noise. Vegetation of $30 \mathrm{~m}$ wide can reduce noise for $5 \mathrm{~dB}$. However, it is not feasible to plant enough trees and other vegetation along the highway to achieve such a reduction. Trees and other types of 
ROAD TRAFFIC AS A SOURCE OF NOISE POLLUTION (CASE STUDY: TRSTENIK MUNICIPALITY)

greenery can be planted due to psychological effects, but not to reduce realistic noise levels.

\section{CASE STUDY FOR CITY TRSTENIK}

The municipality of Trstenik is located in the valley of the Western Morava, on the slopes of Gledić Mountains and Goč. In this area, in 51 settlements, there are approximately 43,000 inhabitants with average population density is $110 \mathrm{inh} / \mathrm{km}^{2}$. City Trstenik is located on the right bank of the West Morava, with more than 17.000 inhabitants.

In the continuation of this paper, it can be seen how a noise level survey was conducted in the city area of the municipality of Trstenik, as well as an analysis of the obtained data.

\subsection{NOISE MEASUREMENT IN LIFE-ENVIRONMENT IN THE MUNICIPALITY OF TRSTENIK FOR THE 2017}

Measurement of noise in the town Trstenik was carried out in accordance with the regulations of the Republic of Serbia (Law on Protection against Noise in the Environment ("Official Gazette of RS", No. 36/09 and 8810, 2009), during the June 2017, with the use of modern equipment.

Measurement methods are applied in accordance with:

- SRPS ISO 1996-1- Description, Measurement and Evaluation of Noise in the Environment - Basic Sizes and Procedures for Evaluation and - SRPS ISO 1996-2 - Describing, measuring and evaluating noise in the environment - Determination of noise levels in the environment.

The used measuring devices which were used are given in Table 1.The calibration was performed before and after the measurement series, and the extended measurement uncertainty (for $95 \%$ confidence level) was $\pm 5 \%$ and with FAST dynamic characteristic. The instrument was used for measuring broadband variabled noise. Measured physical size was an equivalent continuous sound level (Leq) with done spectral terrestrial analysis.

Data processing and verification of input parameters was carried out using software programs BZ5503 and Noise Explorer 7815. The results of the test only refer to the measured measuring points in the measurement terms.

Table 1. Measuring devices

\begin{tabular}{|c|c|c|c|}
\hline Name & $\begin{array}{c}\text { Level gauge } \\
\text { sound }\end{array}$ & $\begin{array}{c}\text { Condenser } \\
\text { michrophone }\end{array}$ & $\begin{array}{c}\text { Acoustic } \\
\text { calibrator }\end{array}$ \\
\hline Manufacturer & $\begin{array}{c}\text { Bruel\&Kjær, } \\
\text { Danska }\end{array}$ & $\begin{array}{c}\text { Bruel\&Kjær, } \\
\text { Danska }\end{array}$ & $\begin{array}{c}\text { Bruel\&Kjær, } \\
\text { Danska }\end{array}$ \\
\hline Type / serial number & BK 2250 & BK 4189 & $4231 / 2583551$ \\
\hline
\end{tabular}




\begin{tabular}{|c|c|c|c|}
\hline & /3009337 & /3022983 & \\
\hline Measuring range & $20-140 \mathrm{~dB}$ & $14,6-146 \mathrm{~dB}$ & \\
\hline The margin of error & class 1 & class 1 & class 1 \\
\hline Frequency & $3 \mathrm{~Hz}-20 \mathrm{kHz}$ & $6,3 \mathrm{~Hz}-20 \mathrm{kHz}$ & $\begin{array}{c}\mathrm{dB}(1000 \pm 1) \\
\mathrm{Hz}\end{array}$ \\
\hline The smallest divider & $0,1 \mathrm{~dB}$ & & \\
\hline Sound level & & & $\begin{array}{l}94 \pm 0,2 \mathrm{~dB} \\
\text { i1 } 14 \pm 0,2\end{array}$ \\
\hline $\begin{array}{c}\text { Digital } \\
\text { thermohygroanemometer }\end{array}$ & \multicolumn{3}{|c|}{$\begin{array}{l}\text { Manufacturer: Nielsen-Kellerman, USA; type: Kestrel } 4000 \text {; serial } \\
\text { number: } 642113 \\
\text { - range (wind speed } 0.6 \text { to } 40 \mathrm{~m} / \mathrm{s} \text {; temperature }-29 \text { to }+70^{\circ} \mathrm{S} \text {; } \\
\text { - air humidity } 5 \text { to } 95 \% \mathrm{RH} \text {, air pressure } 870 \text { to } 1080 \mathrm{mbar} \text { ) }\end{array}$} \\
\hline
\end{tabular}

Source: authors

\subsubsection{Classification of measuring points, description of measuring points and weather conditions}

Based on the Regulation on Noise Indicators, Limit Values, Methods for Assessment of Indicators of Noise, Disturbance and Harmful Effects of Noise in the Environment (Official Gazette of RS 75/10), a classification of measuring points and measuring points has been performed. Selected measuring points were:

1. AMSS Crossroads - settled at the entrance to Trstenik. It is categorized as: city center, craft, commercial, administrative zone with apartments, zones along highways, main and urban roads (belt exposed to direct noise from the main road, 25m width, on both sides of the road (allowed noise level - day and evening $65 \mathrm{~dB}$, night $55 \mathrm{~dB}$ ) Measurement was carried out from the yard of the Auto-Moto Association of Serbia, in the vicinity of the intersection of two very busy streets, surrounded by residential buildings and noise from traffic.

2. Center - Square- settled in front of the Municipality building. It is categorized as: business-residential and commercial-residential area with children's playground; belt exposed to direct noise: from the main road at a depth of 25 to 50 meters, with noisy streets at a depth of $25 \mathrm{~m}$ on both sides of the road (allowed noise level - day and evening $60 \mathrm{~dB}$, night $50 \mathrm{~dB}$ ). The space is connected to multi-store buildings. Noise originates from traffic and citizenship activities.

3. Prva petoletka - surroundings of the mechanical industry. It is categorized as: City center, craft, commercial, administrative-upravna zone with apartments, zone along highways, main and city roads (belt exposed to direct noise from the main road, $25 \mathrm{~m}$ width, on both sides of the road) day and night $65 \mathrm{~dB}$, night $55 \mathrm{~dB}$; areas for rest and recreation, hospital zones and rest areas, cultural and historical sites, large parks (dosing noise: day and night 50 $\mathrm{dB}$, night $40 \mathrm{~dB}$ ). The measurement was done in front of the factory's main 
gate. The street is surrounded by terraced and one-storey residential buildings. Noise originates mainly from traffic.

4. Health Center "MD Sava Stanojevic" - area is classified in the category: recreation and recreation areas, hospital zones and rest areas, cultural and historical sites, large parks (dosing noise - day and night $50 \mathrm{~dB}$, night $40 \mathrm{~dB}$ ). The measurements were made in the compound of the Health Center "MD Sava Stanojevic" in Vuka Karadzic Street, on the green area in front of emergency aid. The street is decorated with terraced and multi-storey buildings for different purposes. The noise comes from traffic and citizens' activities.

During measurement time (09:00, 11:00, 20:00, 22:00 and 00:00 hours) at all locations, weather conditions could not endanger the reliability of the measurement (the temperature was ranged from $18{ }^{\circ} \mathrm{C}$ to $25^{\circ} \mathrm{C}$, wind was NW with velocity from $2.9 \mathrm{~m} / \mathrm{s}$ to $3.7 \mathrm{~m} / \mathrm{s}$, humidity of air was from $53 \%$ up to $83 \%$, and the atmosphe pressure was ranged from $999.8 \mathrm{mb}$ to 1000.3 $\mathrm{mb})$.

\subsubsection{Measurement results per locations}

For the selected locations, the measurement rhythm was determined and given in Table 2. In Table 3, data collected from measuring points can be seen. The graphical presentation of the spectral analysis is also shown on Figure 4 (in the terrestrial range from $12.5 \mathrm{~Hz}$ to $50 \mathrm{~Hz}$ and from $10.000 \mathrm{~Hz}$ to $16.000 \mathrm{~Hz}$, which is outside the scope of accreditation, ie outside the indicated terrestrial ranges with central frequencies values from $50 \mathrm{~Hz}$ to $10.000 \mathrm{~Hz}$ given in the SRPS ISO 1996-2 method). Figures 2 and 3 show the measuring points.

Figure 2. Measuring points -AMSS and Center
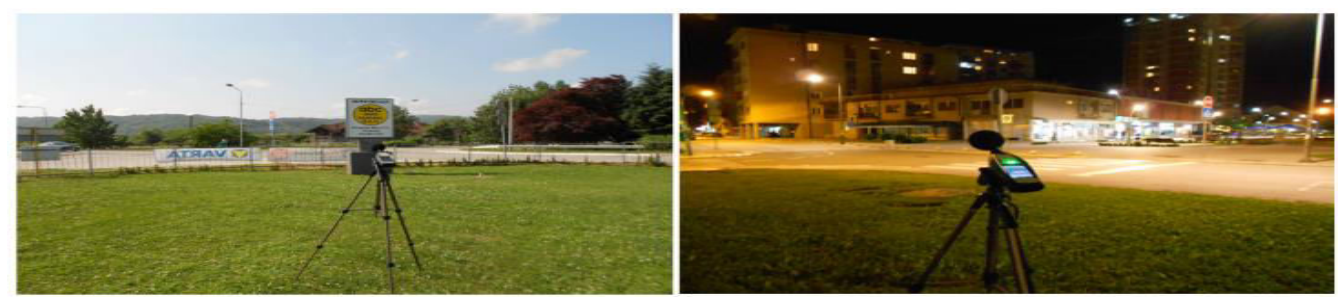

Source: authors 
Figure 3. Measuring points - Health center and Prva petoletka (authors)
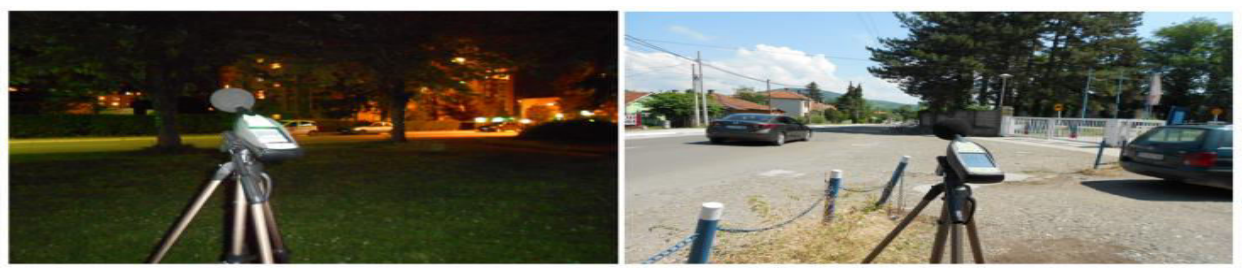

Source: authors

Table 2. Measurement intervals

\begin{tabular}{|c|c|c|c|c|c|}
\hline $\begin{array}{c}\text { Reference } \\
\text { time } \\
\text { interval }\end{array}$ & \multicolumn{2}{|c|}{$\begin{array}{c}\text { Daily period } \\
\text { 06-18h } \\
19.06 .2017 .\end{array}$} & \multicolumn{2}{c|}{$\begin{array}{c}\text { Evening period } \\
\text { 18-22h } \\
19.06 .2017 .\end{array}$} & $\begin{array}{c}\text { Night time } \\
\mathbf{2 2 - 0 6 h} \\
\text { 19. and } \\
\mathbf{2 0 . 0 6 . 2 0 1 7}\end{array}$ \\
\hline $\begin{array}{c}\text { Measurement } \\
\text { interval }\end{array}$ & \multicolumn{2}{|c|}{ T=15 minutes } \\
\hline $\begin{array}{c}\text { measurement } \\
\text { intervals }\end{array}$ & I & II & III & IV & V \\
\hline $\begin{array}{c}\text { Measurement } \\
\text { period }\end{array}$ & $\mathbf{0 9 - 1 1 h}$ & $\mathbf{1 1 - 1 3 h}$ & $\mathbf{2 0 - 2 2 h}$ & $\mathbf{2 2 - 0 0 h}$ & $\mathbf{0 0 - 0 2 h}$ \\
\hline $\begin{array}{c}\text { Energ. equivalent } \\
\text { level, Leq }\end{array}$ & $\begin{array}{c}\text { Dynamic } \\
\text { characteristics } \\
\text { instrument } \\
\text { FAST }\end{array}$ & & & & \\
\hline $\begin{array}{c}\text { Characteristics } \\
\text { of noise } \\
\text { (Official Gazette } \\
\text { RS 72/10) }\end{array}$ & $\begin{array}{c}\text { Time: Variable } \\
\text { noise }\end{array}$ & $\begin{array}{c}\text { Frequency: } \\
\text { Broadband noise }\end{array}$ & & & \\
\hline
\end{tabular}

Source: authors

Table 3. Measuring points with results of measurement

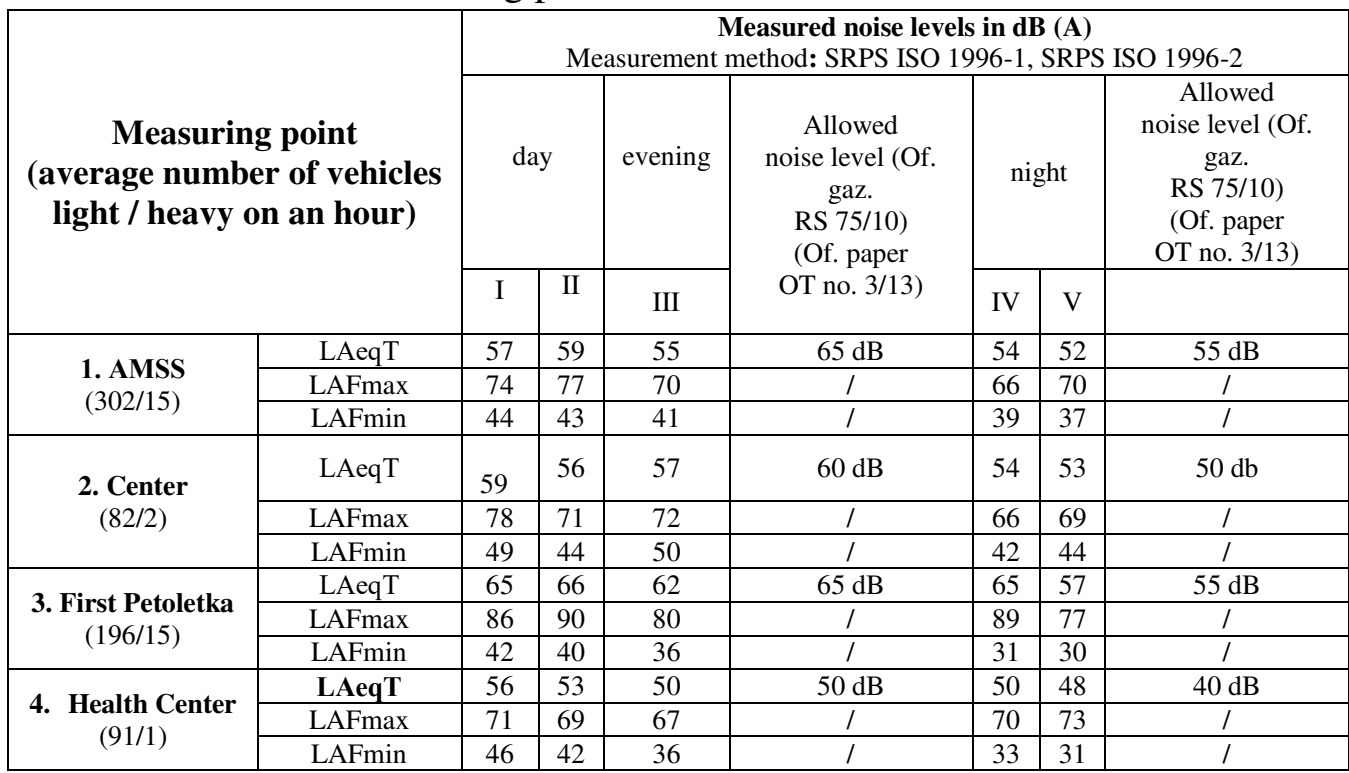

Source: authors 
For Table 2 and 3- *LAeqT - equivalent noise level with A weighting, LAFmax - maximum noise level with FAST, LAFmin - minimum noise level with FAST indicator)

Figure 4. Spectral analysis at measuring points (1,2,3 and 4)

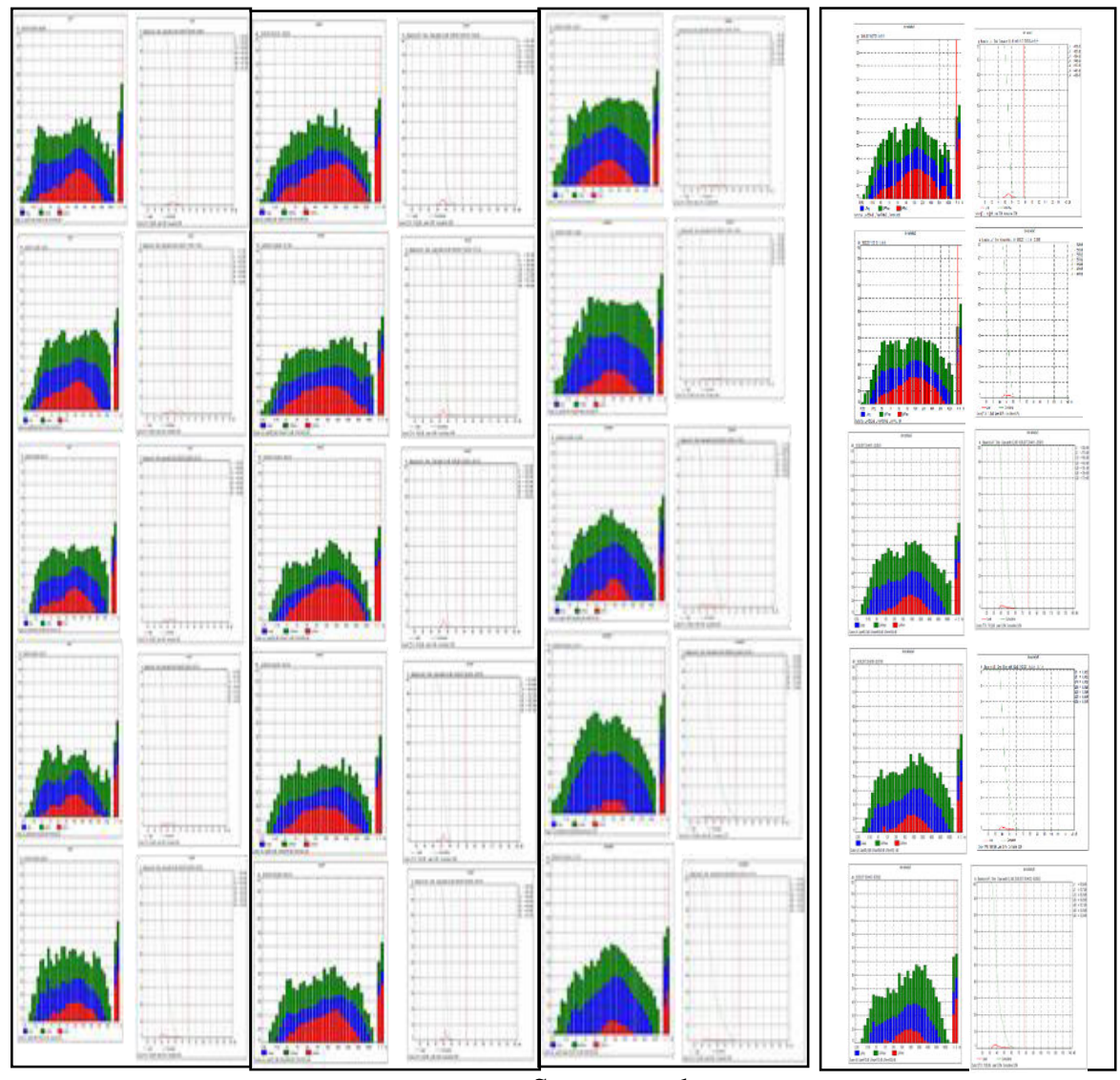

Source: authors

\subsection{INTERPRETATION OF THE RECEIVED RESULTS}

Conclusions were drawn for each measuring point:

\section{Measuring point 1 - AMSS}

For the area located along main and urban roads with a residential area, the measured noise values were up to $59 \mathrm{~dB}$ for a day $55 \mathrm{~dB}$ in the evening and for night up to $54 \mathrm{~dB}$. There were no overruns over the day and evening, even during the night. During the measurement it was found that noise has a continuous flow in the environment and that it originates from traffic. The average number of vehicles on the measuring intervals was 302 light and 15 heavy vehicles per hour. 


\section{Measuring point 2 - Center}

For the city center area, located along urban roads with a residential area, the measured values of the external noise were up to $59 \mathrm{~dB}$ for a day, $57 \mathrm{~dB}$ for evening and for night $54 \mathrm{~dB}$. There were no overruns over the day and evening, but during the night there were overruns of up to $4 \mathrm{~dB}$. During the measurement, it was found that the noise in the environment is a continuous flow and that it mostly originates from traffic. The average number of vehicles on the measuring place was: light 82 and 2 heavy per hour.

\section{Measuring point 3 - Prva petoletka}

For the area located along main and urban roads with residential areas, the measured noise values were up to $66 \mathrm{~dB}$ for a day, $62 \mathrm{~dB}$ for evening and for night up to $65 \mathrm{~dB}$. Exceeding the noise level during the day was up to $1 \mathrm{~dB}$, during the evening there was no overrun, and during the night there were overruns of up to $10 \mathrm{~dB}$. During the measurement it was found that noise in the environment is a continuous flow and that it originates from traffic. The average number of vehicles on the measuring site was 196/15 light and weight per hour, retrospectively.

\section{Measuring point 4 - Health Center}

For a space surrounded by medical objects, the measured external noise values were up to $56 \mathrm{~dB}$ for a day, for the evening $50 \mathrm{~dB}$ and $50 \mathrm{~dB}$ for the night. Exceeding the noise level during the day was up to $6 \mathrm{~dB}$, during the evening there was no overrun, and during the night there were overruns of up to $10 \mathrm{~dB}$. During the measurement, it was found that the noise in the environment has a non-continuous flow and that most of it originates from traffic. The average number of vehicles on the measuring place was 91/1light and weight per hour, retrospectively.

\section{CONCLUSION}

Over $50 \%$ of EUs population is everyday interupted by noise, more than $16 \%$ of EU citizens live in black accustic zones, slipping is interrupted by noise during sleep among $30 \%$ of EU citizens and more than $12 \%$ of worlds population is in danger of loosing hearing caused by noise. For this reason, more and more attention is paid to limiting the noise coming from motor vehicles. (http://www.zavodks.co.rs/izvestaji/buka)

This research showed that the level of noise in the municipality of Trstenik is not within the allowed limits. Measured noise values in the environment, with overruns especially during night, may adversely affect the rest and general health of people, especially if their effect is of a more recent character.

From results it could be concluded: 
- in zones along main and city roads, significant overruns of noise level were measured for night measurement at the measuring point 3

- In the business-residential area, (measuring point 2) noise levels exceeded allowed level during nighttime measuring,

- In the zone surrounded by health facilities and recreation areas, (measurement place 4), overruns were measured during the day and overnight ,

- the location where the smallest oscillations are recorded is the measurement place Center.

- the overload level of noise on observed points were up to $6 \mathrm{~dB}(\mathrm{~A})$ during the evening and up to $10 \mathrm{~dB}(\mathrm{~A})$ during the night and

- Noise in the environment, at the observed points, originates from traffic (buses, heavy trucks and light vehicles).

Further research should inspect deeper connections between noise and health problems of the population. In the meantime, in order to improve managing noise levels, it is necessary to: identify the so-called black, gray and white acoustic zones; carry out a sharper control of redirecting heavy vehicles to the roads around the city, increase control of the noise emitted by motor vehicles during the technical inspection and daily traffic; continue with extending the network of streets with automatic traffic regulation and synchronization of traffic lights in certain directions; introduce time pieces on traffic lights that last more than 1 minute, especially at intersections with magistral significance; plan the installation of green and protective belts and arrange multi-storey plantations of various woody along traffic roads in order to reduce the level of municipal noise.

All of this would significantly affect the quality of people's lives and reduce the subsequent costs of remedying the effects of noise.

\section{REFERENCES}

1. Alessandroni, G., Carini, A., Lattanzi, E., Freschi, V. and Bogliolo, A. 2017. A study on the influence of speed on road roughness sensing: The SmartRoadSense case. Sensors, 17(2), p. 305.

2. Botteldooren, D., Dekoninck, L. and Gillis, D. 2011. The influence of traffic noise on appreciation of the living quality of a neighborhood. International journal of environmental research and public health, 8(3), pp. 777-798.

3. Panulinová, E. and Harabinová, S. 2013. The noise pollution problem in the tram route. 13th SGEM GeoConference on Ecology, Economics, Education and Legislation, 1 (International Multidisciplinary Scientific GeoConference SGEM2013), 1059-1064. 
4. Fernandes de Souza, T.C., Santos Périsé A.R. and Moura, M. 2015. Noise exposure and hypertension: investigation of a silent relationship. $B M C$ Public Health, 15(1), 328.

5. Grubiša, M. 2013. Zaštita od buke i vibracije, Kragujevac.

6. Jakovljevic, B., Paunovic, K. and Belojevic, G. 2009. Road-traffic noise and factors influencing noise annoyance in an urban population. Environment international, 35(3), pp. 552-556.

7. Kostadinović S., Grujić M., 2003. Strategija razvoja saobraćaja. Beograd: Grafo-žig.

8. Mihajlović P., Stošić Lj. 2016. Urbani menadžment i upravljanje životnom sredinom u gradu u uslovima permanentnog intenziviranja saobraćaja, 4. Međunarodna konferencija: Savremena dostignuća u građevinarstvu. Subotica: Građevinski fakultet Univerziteta u Novom Sadu.

9. Morillas, J. B., Escobar, V. G., Sierra, J. M., Gómez, R. V. and Carmona, J. T. 2002. An environmental noise study in the city of Cáceres, Spain. Applied acoustics, 63(10), pp. 1061-1070.

10. Wszołek, T. 2017. Cumulative industrial noise impact on the environment. Archives of Acoustics, 42(2), pp. 169-174.

11. Zatežić, M., Mujić, D. Ž. And Biočanin, I. 2009. Saobraćaj i životna sredina u sistemu kvaliteta. In: ICAMA 1st International Conference, Banja Luka: Panevropski Univerzitet Aperion.

12. Portal građevinske industrije, 2011. Barijere za zaštitu od saobraćajne buke. [online] Available at: <https://www.gradjevinarstvo.rs/tekstovi/1729/820/barijere-za-zastitu-odsaobracajne-buke> [Accessed 11 November 2018].

13. Izveštaj o realizaciji G2G projekta za Srbiju G2G09/SB/5/5. 2011. Smanjenje saobraćajne buke u Srbiji. Beograd: JP Putevi Srbije.

14. Izveštaj o ispitivanju - merenju buke, 2016. Odeljenje za higijenu i humanu ekologiju. Kruševac: Zavod za javno zdravlje.

15. Sustainable Mobility Initiatives for Local Environment consortium, 2003. Guidelines for road traffic noise abatement [pdf] Sustainable Mobility Initiatives for Local Environment. Available at: $<$ http://ec.europa.eu/environment/life/project/Projects/index.cfm?fuseacti on=home.showFile\&rep=file \&fil=SMILE_guidelines_noise_en.pdf $>$ [Accessed 10 October 2018].

16. Directorate General for Internal Policies of the Union, 2012. Reducing Railway pollution [pdf] Directorate General for Internal Policies of the Union. Available at: <http://www.europarl.europa.eu/RegData/etudes/etudes/join/2012/474533 /IPOL-TRAN_ET(2012)474533_EN.pdf> [Accessed 10 October 2018].

17. Zavod za javno zdravlje Kruševac, 2017. Izveštaj - buka [online] Zavod za javno zdravlje Kruševac. Available at: <http://www.zavodks.co.rs/izvestaji/buka> [Accessed 12 October 2018]. 
ROAD TRAFFIC AS A SOURCE OF NOISE POLLUTION (CASE STUDY: TRSTENIK MUNICIPALITY)

18. Uredba o indikatorima buke, graničnim vrednostima, metodama za ocenjivanje indikatora buke, uznemiravanja $i$ štetnih efekata buke $u$ životnoj sredini $i$ na zdravlje ljudi, kao i vrstama i načinu prikupljanja podataka potrebnih za njihovo ocenjivanje (,,Službeni glasnik RS”, broj 75/10). Beograd: Službeni glasnik Republike Srbije.

19. International Organization for Standardization. 1996. Acoustics Description, measurement and assessment of environmental noise Basic quantities and assessment procedures (SRPS ISO 1996-1:2010).

20. International Organization for Standardization. 1996. Acoustics Description, measurement and assessment of environmental noise Determination of environmental noise levels (SRPS ISO 1996-2:2010).

21. Zakon o zaštiti od buke u životnoj sredini (,,Službeni glasnik RS”, broj 36/09 i 8810). Beograd: Službeni glasnik Republike Srbije.

Received: 21 November, 2018

Revised: 11 April, 2019

Accepted: 17 June, 2019 
